\title{
Genetic susceptibility to early onset pauciarticular juvenile chronic arthritis: a study of HLA and complement markers in 158 British patients
}

\author{
P J HALL, ${ }^{1} \mathrm{~S}$ J BURMAN, ${ }^{1} \mathrm{M}$ R LAURENT ${ }^{2}$ D C BRIGGS, ${ }^{2}$ H E VENNING, \\ A M LEAK, ${ }^{1}$ P A BEDFORD, ${ }^{1}$ AND B M ANSELL ${ }^{1}$ \\ From the 'Clinical Research Centre, Harrow; and 'Guy's Hospital, London
}

SUMMARY To investigate the genetics of susceptibility to early onset pauciarticular juvenile chronic arthritis (JCA), 158 unrelated ethnic British patients with a mean disease onset of $3 \cdot 2$ years, together with controls, were tested for HLA-A, B, C, and DR antigens. Additionally, 117 patients were also investigated for complement $\mathrm{Bf}$ and $\mathrm{C} 4$ markers. New observations included an increased frequency of the C4B 2 allotype ( $p$ corrected $\left.\left(p_{c}\right)<0 \cdot 02\right)$ and C4A 4,B 2 phenotype $(\mathrm{p}<0.0005)$. Findings suggested a unique increase of the haplotype HLA-DRw8, Bf*S, C4A*4, $\mathrm{C} \mathrm{B}^{*} 2$, HLA-B39, possibly predisposing to more severe disease. Strong positive associations were confirmed with HLA antigens A2 $\left(\mathrm{p}_{\mathrm{c}}=2 \cdot 5 \times 10^{-8}\right)$, DRw8 $\left(\mathrm{p}_{\mathrm{c}}=3.5 \times 10^{-14}\right)$, DR5 $\left(\mathrm{p}_{\mathrm{c}}<0 \cdot 02\right)$, DRw52 $\left(p_{c}=2 \cdot 8 \times 10^{-6}\right)$ and DR5, w8 phenotype $\left(p_{c}=3.9 \times 10^{-6}\right)$, and negative associations with DR7 $\left(p_{c}=5.8 \times 10^{-7}\right)$, DR4 $\left(p_{c}<0.002\right)$, and DRw53 $\left(p_{c}=0.004\right)$. Antinuclear antibody (ANA) seropositivity correlated with DR5 $(\mathrm{p}<0.02)$, and in children with chronic iridocyclitis (CIR) Bw62 incidence was raised $(p<0.03)$ and $B 44$ reduced $(p<0.03)$. HLA-A2 was found in $88 \%$ of ANA +, CIR + patients $(p<0 \cdot 01)$. A significant excess of DR5, w8 heterozygotes was present (relative risk $=41 \cdot 1$ ) and a lack of corresponding homozygotes. Results are inconsistent with a recessive, dominant, or intermediate mode of inheritance of susceptibility, and favour the existence of at least two DR linked 'disease' genes. Moreover, there may be an interaction in heterozygotes of combinatorial factors associated with DR5 and DRw8 in enhancing susceptibility. Possible immunogenetic mechanisms underlying the observed associations with three antigen classes are discussed. Evidence here suggests a role for the HLA-DQ locus in determining susceptibility to this disease.

Key words: major histocompatibility complex, genetic associations, linkage disequilibrium, inheritance, immunogenetics.

Juvenile chronic arthritis (JCA) is a heterogeneous group of disorders ${ }^{12}$ which is presently subclassified by the mode of onset into systemic, polyarthritic, or pauciarticular (four or fewer joints). This last type can be further divided into those under 9 years, showing a female predominance, often with chronic iridocyclitis (CIR) and antinuclear antibodies (ANA), those over 9 years, usually HLA-B27 positive boys, and others, which include patients with psoriasis.

Accepted for publication 23 October 1985.

Correspondence to Dr P J Hall, Clinical Research Centre, Division of Rheumatology, Watford Road, Harrow, Middlesex HA1 3UJ.
The pauciarticular onset form of JCA shows multiple associations with HLA antigens, viz A2, B39, DR5, Dw5, DRw6, DRw8, Dw8, MT1, and MT2 (now DQw1, DRw52 respectively), and B44, B35 in linkage with DR5. ${ }^{3-20}$ Family studies have demonstrated increased haplotype sharing among affected sibling pairs. ${ }^{19} 2122$ In addition, increased frequencies of the complement haplotypes $\mathrm{C}_{4} \mathrm{~A}^{*} 3$, $\mathrm{C}^{\mathrm{B}} \mathrm{B}^{*} 1, \mathrm{Bf}^{*} \mathrm{~S}$, and $\mathrm{C} 4 \mathrm{~A}^{*} 3, \mathrm{C} 4 \mathrm{~B}^{*} 2, \mathrm{Bf}^{*} \mathrm{~S}$ in early onset cases were reported, ${ }^{23}$ while two studies of complement allotypes in pauci-JCA showed no significant deviations in distribution. ${ }^{19} 24$ These studies have shown the involvement of genetic factors in pauciJCA, but the disease aetiology, pathogenetic 
mechanisms, and mode of inheritance of susceptibility remain undefined.

The reported distribution of antigens associated with pauci-JCA has varied between studies. This might be due to lack of clinical homogeneity, small sample size, racial heterogeneity, and the problems encountered in defining the cross reacting specificities DR5, DRw6, and DRw8, especially when two are present together.

This article describes the genetic aspects of susceptibility to early onset pauciarticular JCA in a clinically well defined group of 158 unrelated patients of British origin. All patients and controls were typed for 67 HLA-A, B, C, and DR antigens. Additionally, 117 patients were also investigated for 38 complement factor $\mathrm{B}(\mathrm{Bf})$ and $\mathrm{C} 4$ allotypes.

\section{Patients and methods}

\section{SUB JECTS}

The study comprised 158 patients classified as having pauciarticular onset JCA (EULAR-WHO criteria, 1977), with a mean age of onset of $3 \cdot 2$ years (range 6 months -9 years). All were unrelated, white Caucasians of British extraction. The mean duration of disease was $10 \cdot 4$ years (range 2.5-38 years). The majority of these patients were in ongoing studies relating to (a) ANA and CIR in juvenile chronic arthritis and $(b)$ extending arthritis after a pauciarticular onset. There was therefore a predominance of patients with ANA and also of those in whom disease had extended beyond four joints. One hundred and twenty two patients $(77 \%)$ were female and $36(23 \%)$ male, all were IgM rheumatoid factor negative, $110(70 \%)$ had ANA present in their serum, and $84(53 \%)$ had developed CIR. Forty one $(26 \%)$ cases persisted with pauciarticular disease, $47(30 \%)$ had extended to five to nine joints, and $70(44 \%)$ had over nine joints involved. Recorded data were computer based to facilitate analysis.

Controls for the HLA analysis were ethnically matched and comprised 192 random, unrelated, normal individuals, tissue typed either in our laboratory or comparably typed in the Imperial Cancer Research Fund Laboratories, London by Dr Julia Bodmer and staff. Complement allotype distribution in the patients was compared with that of a similar control panel of 200 British subjects typed by Dr K Welsh and colleagues at Guy's Hospital, London.

\section{HLA TYPING}

Fifty five HLA-A, B, and C specificities were tested with a standardised panel of 180 established antisera. The DR typing panel consisted of 60 well validated antisera recognising the antigens DR1 to DRw10, DRw52, and DRw53, obtained from sources both in the UK and abroad, and included 22 sera employed in the 8th International Histocompatibility Workshop. Emphasis was placed on the definition of the related specificities DR5, DRw6, DRw8, and their assignments have been subsequently confirmed on the 9th Workshop typing sets. Typing was carried out by standard, two stage microlymphocytotoxicity visualised for the HLA-A, $B$, and $C$ antigens by a modified two colour cytofluorochromasia procedure, ${ }^{25}$ and for the DR antigens by two colour fluorescence on unseparated B cells. ${ }^{26}$

\section{COMPLEMENT ALLOTYPING}

In addition, 117 of the patients together with controls were tested for $34 \mathrm{C} 4 \mathrm{~A}$ and C4B allotypes of the classical complement pathway and four $\mathrm{Bf}$ allotypes of the alternative pathway.

C4 allotypes were detected by high voltage electrophoresis of desialated plasma, according to the method of Awdeh and Alper, ${ }^{27}$ using a functional assay to discriminate between $\mathrm{C} 4 \mathrm{~A}$ and $\mathrm{C} 4 \mathrm{~B}$ variants. $C 4$ 'null' alleles were assigned in single heterozygotes (i.e., in individuals with a 'null' allele at either the A or B locus) on the basis of the ratio of $\mathrm{C} 4 \mathrm{~A} / \mathrm{C} 4 \mathrm{~B}$ products as determined by densitometric scanning of the stained typing gels. Although family studies are required for accurate assignment of all null alleles, scanning can give information on the zygosity of the C4 loci and should detect most single heterozygotes. ${ }^{28}$ This has been confirmed by one of us in extensive family studies (DCB, unpublished observations).

Factor B (Bf) allotypes were determined by the same method, that is, with trometamol (TRIS)-

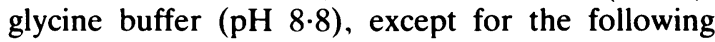
differences: $0.4 \mathrm{~g} / \mathrm{l}$ calcium lactate was added to the tank buffer and $0 \cdot 2 \mathrm{~g} / \mathrm{l}$ was added to the gel buffer (1:4 tank buffer). Samples were not pretreated with neuraminidase for $\mathrm{Bf}$ allotyping, nor were any functional tests done: $\mathrm{Bf}$ allotype patterns were visualised by staining after immunofixation and washing.

\section{STATISTICAL METHODS}

Fisher's exact test (one sided) was used to evaluate comparisons of the frequencies of the genetic markers in patients and controls. ${ }^{29}$ For the total study analysis the $p$ values were corrected for the number of antigens tested $\left(p_{c}\right)$. Relative risks (RR) were calculated by Woolf's method, with Haldane's correction applied whenever a value was null. ${ }^{30}$ In addition to the traditional RR, the degree of positive association was estimated for the total study 
Table 1 Selected $H L A-A, B$, and $C$ antigen frequencies $(\%)$ in pauci-JCA patients and controls

\begin{tabular}{|c|c|c|c|c|c|}
\hline$H L A$ & $\begin{array}{l}\text { Patients } \\
(n=158)\end{array}$ & $\begin{array}{l}\text { Controls } \\
(n=192)\end{array}$ & $\begin{array}{l}\text { Relative } \\
\text { risk }\end{array}$ & $\begin{array}{l}\text { Aetiologic } \\
\text { fraction } \\
\text { (d) }\end{array}$ & $\begin{array}{l}\text { Fisher's } \\
p_{c}\end{array}$ \\
\hline A2 & $78 \cdot 6$ & $46 \cdot 8$ & $4 \cdot 2$ & $0 \cdot 60$ & $2.5 \times 10^{-x}$ \\
\hline B27 & 9.4 & $6 \cdot 3$ & 1.5 & & NS \\
\hline B35 & $11 \cdot 3$ & $16 \cdot 6$ & $0 \cdot 6$ & & NS \\
\hline B39 & $15 \cdot 7$ & 4.9 & $3 \cdot 6$ & $0 \cdot 11$ & $3.2 \times 10^{-2}$ \\
\hline B44 & $31 \cdot 4$ & $30 \cdot 2$ & $1 \cdot 1$ & & NS \\
\hline Bw57 & $1 \cdot 3$ & $9 \cdot 2$ & $0 \cdot 1$ & & NS \\
\hline Bw60 & $26 \cdot 4$ & $9 \cdot 2$ & $3 \cdot 5$ & $0 \cdot 19$ & $8.8 \times 10^{-4}$ \\
\hline Bw62 & $14 \cdot 5$ & $9 \cdot 3$ & 1.7 & & NS \\
\hline Cw6 & $5 \cdot 1$ & 21.4 & 0.2 & & $5.4 \times 10^{-4}$ \\
\hline $\mathrm{C}$ blank & 49.7 & $68 \cdot 6$ & 0.4 & & $1.7 \times 10^{-2}$ \\
\hline
\end{tabular}

NS=not significant at the $5 \%$ probability level.

group with the $\delta$ value of Bengtsson and Thomson. ${ }^{31}$ This value is identical to the so called 'population attributable risk' or 'aetiologic fraction' (EF) well known in epidemiology. ${ }^{32}$ For decreased risks the 'preventive fraction' (PF) was used. ${ }^{32}$ These values give direct measures in genetical terms of the strength of the association between a disease susceptibility or resistance gene and an HLA allele.

Linkage disequilibria (absolute delta or $\Delta$ ) between loci were computed from the $2 \times 2$ table of phenotype frequencies by the formula of Mattiuz $e t$ $a l,,^{33}$ and the significance assessed by the $\chi^{2}$ value with Yates's correction and Fisher's exact method. Haplotype frequencies (HF) were obtained from the sum of the product of the gene frequencies and the delta value. The magnitude of the delta value (relative delta or $\Delta r$ ) was calculated from the formula defined by Baur and Danilovs. ${ }^{34}$ Three point linkage disequilibrium was analysed as described by Piazza. ${ }^{35}$

\section{Results}

DISTRIBUTION OF GENETIC MARKERS IN

THE TOTAL STUDY GROUP

$H L A$ and complement allotypes

The results for HLA-A, B, and C antigens, which either showed altered frequency compared with controls or were of special interest, are listed in Table 1. There was a highly significant increase of $A 2$, giving an EF value of $0 \cdot 60$. Of those $B$ locus antigens deviating from normal, the raised levels of $\mathrm{B} 39$ and Bw60 remained significant after correction. Significantly lowered frequencies of $\mathrm{C}$ locus blanks, and particularly Cw6, were seen.

Relative to controls, a marked disturbance in the distribution of DR antigens in the patients was found, as shown in Table 2. The frequencies of DR5 and DRw8 were increased, the latter being associated with a high risk of the disease $(\mathrm{RR}=12 \cdot 8)$. The incidence of DRw6 was also raised but not significantly. Both DR4 and DR7 were much reduced. The low level of DR7 was most significant, with a substantial PF value of $0 \cdot 28$; presence of this antigen carries a fivefold decreased risk of contracting the disease. The two cross reacting groups of DR antigens, DR3, 5, w6, w8 and DR4, 7, w9 were fully included in the 'supertypic' specificities DRw52 and DRw53 respectively, which is reflected in the significant increase of DRw52 and decrease of DRw53.

At the $\mathrm{C} 4$ loci the frequency of the C4B 2 marker was increased significantly (Table 3 ). Among the high risk group of DR5, w8 heterozygotes (vide infra) the incidence of this allotype was found to be even higher $(46 \%)$. C4A 4 was also raised, though this was not significant after correction. No differences were seen in the distribution of the Bf alleles.

Table 2 HLA-DR antigen frequencies (\%) in pauci-JCA patients and controls

\begin{tabular}{|c|c|c|c|c|c|c|}
\hline$H L A$ & $\begin{array}{l}\text { Patients } \\
(n=158)\end{array}$ & $\begin{array}{l}\text { Controls } \\
(n=192)\end{array}$ & $\begin{array}{l}\text { Relative } \\
\text { risk }\end{array}$ & $\begin{array}{l}\text { Aetiologic } \\
\text { fraction } \\
\text { (d) }\end{array}$ & $\begin{array}{l}\text { Preventive } \\
\text { fraction }\end{array}$ & $\begin{array}{l}\text { Fisher's } \\
p_{c}\end{array}$ \\
\hline DR1 & $14 \cdot 6$ & $19 \cdot 8$ & 0.7 & & & NS \\
\hline DR2 & $22 \cdot 2$ & $28 \cdot 1$ & 0.7 & & & NS \\
\hline DR3 & $24 \cdot 7$ & $27 \cdot 6$ & 0.9 & & & NS \\
\hline DR4 & 9.5 & $26 \cdot 6$ & $0 \cdot 3$ & & $0 \cdot 19$ & $1.9 \times 10^{-3}$ \\
\hline DR5 & $30 \cdot 1$ & $14 \cdot 1$ & $2 \cdot 6$ & $0 \cdot 18$ & & $1.5 \times 10^{-2}$ \\
\hline DRw6 & $33 \cdot 8$ & $22 \cdot 0$ & $1 \cdot 8$ & $0 \cdot 15$ & & NS \\
\hline DR7 & $8 \cdot 9$ & $33 \cdot 8$ & $0 \cdot 2$ & & 0.28 & $5.8 \times 10^{7}$ \\
\hline DRw8 & $39 \cdot 2$ & 4.8 & $12 \cdot 8$ & $0 \cdot 36$ & & $3.5 \times 10^{-1}$ \\
\hline DRw9 & $5 \cdot 1$ & 1.0 & $5 \cdot 1$ & & & NS \\
\hline DRw10 & $0 \cdot 6$ & $1 \cdot 1$ & 0.5 & & & NS \\
\hline DRw52 & $85 \cdot 4$ & $59 \cdot 4$ & $4 \cdot 0$ & 0.64 & & $2.8 \times 10^{-6}$ \\
\hline DRw53 & $22 \cdot 8$ & $42 \cdot 7$ & 0.4 & & $0 \cdot 25$ & $4.0 \times 10^{-3}$ \\
\hline
\end{tabular}


Table 3 Bf and selected C4 complement allotype frequencies (\%) in pauci-JCA patients and controls

\begin{tabular}{|c|c|c|c|c|}
\hline $\begin{array}{l}\text { Comp- } \\
\text { lement }\end{array}$ & $\begin{array}{l}\text { Patients } \\
(n=117)\end{array}$ & $\begin{array}{l}\text { Controls } \\
(n=200)\end{array}$ & $\begin{array}{l}\text { Relative } \\
\text { risk }\end{array}$ & $\begin{array}{l}\text { Fisher's } \\
p_{c}\end{array}$ \\
\hline \multicolumn{5}{|l|}{ C4 } \\
\hline AQO & $30 \cdot 8$ & $22 \cdot 7$ & 1.5 & NS \\
\hline A2 & $6 \cdot 8$ & $15 \cdot 0$ & 0.4 & NS \\
\hline A3 & $75 \cdot 2$ & $86 \cdot 0$ & 0.5 & NS \\
\hline A4 & $17 \cdot 1$ & $6 \cdot 8$ & $2 \cdot 8$ & NS \\
\hline A6 & $2 \cdot 6$ & $8 \cdot 7$ & $0 \cdot 3$ & NS \\
\hline BQO & $23 \cdot 9$ & $29 \cdot 5$ & 0.7 & NS \\
\hline B1 & $83 \cdot 8$ & $93 \cdot 2$ & 0.4 & NS \\
\hline B2 & $31 \cdot 6$ & $15 \cdot 0$ & $2 \cdot 6^{\circ}$ & $1.6 \times 10^{-2}$ \\
\hline \multicolumn{5}{|l|}{ Bf } \\
\hline $\mathbf{F}$ & $36 \cdot 8$ & $42 \cdot 7$ & $0 \cdot 8$ & NS \\
\hline F1 & 1.9 & $1 \cdot 0$ & 1.9 & NS \\
\hline $\mathbf{S}$ & $87 \cdot 4$ & 85.4 & $1 \cdot 2$ & NS \\
\hline $\mathrm{SO} \cdot 7$ & $00 \cdot 0$ & $2 \cdot 5$ & $0 \cdot 2$ & NS \\
\hline
\end{tabular}

$\operatorname{EF}(\delta)=0 \cdot 20$

\section{HLA and complement phenotypes}

Eighteen patients carried DR5, w8 (11.4\%), 14 DRw6, w8 $(8.9 \%)$, and 12 DR3, w8 $(7 \cdot 6 \%)$. The increased presence of the DRw8, X heterozygote gave a relative risk of 6.8 (Table 4 ), whereas the DR5, X RR value was 1.5 . The DR5, w8 heterozygote showed the most significant increase, conferring a high risk of the disease $(R R=24 \cdot 6)$. This contrasted with the absence of risk for DR5 or DRw8 homozygotes. It was notable that $58 \%$ of the patients carried DR5 or DRw8, or both, compared with $20 \%$ in the controls.

Both the HLA-B39, DRw8, and C4A 4, C4B 2 phenotypes were significantly more frequent in patients than controls $\left(p=1.6 \times 10^{-6}, 4.1 \times 10^{-4}\right.$ respectively). Of $36 \mathrm{C} 4 \mathrm{~B} 2$ positive cases, 23 also carried DRw8, with a phenotype frequency of $19 \cdot 8 \%$. Direct comparison with controls was not possible, but in view of the low control frequency of
Table 5 Selected haplotype frequencies and linkage disequilibria $(\Delta)$ between the HLA and $C 4$ loci in pauci-JCA patients"

\begin{tabular}{|c|c|c|c|c|}
\hline Haplotype & Frequency & $\Delta$ & $x^{2}$ & Fisher's $p$ \\
\hline HLA-A2, B44 & 0.099 & 0.021 & $0 \cdot 8$ & NS \\
\hline A2, Bw60 & 0.077 & $0 \cdot 015$ & 0.4 & NS \\
\hline A2, Bw62 & $0 \cdot 055$ & 0.021 & 1.8 & NS \\
\hline B39, DRw8 & 0.068 & 0.052 & $27 \cdot 2$ & $9.7 \times 10^{-8}$ \\
\hline$C 4 A^{*} 4, B^{*} 2$ & 0.091 & 0.074 & $48 \cdot 4$ & $9.4 \times 10^{-13}$ \\
\hline$A * 4, B 39$ & 0.027 & 0.018 & $4 \cdot 0$ & $4.4 \times 10^{-2}$ \\
\hline $\mathrm{B} * 2, \mathbf{B} 39$ & 0.063 & 0.048 & $18 \cdot 6$ & $1.3 \times 10^{-6}$ \\
\hline$A * 4, \quad D R w 8$ & 0.039 & 0.020 & $2 \cdot 0$ & NS \\
\hline B*2, DRw8 & 0.090 & 0.054 & $10 \cdot 5$ & $1.2 \times 10^{-3}$ \\
\hline \multicolumn{5}{|l|}{ DRw8, C4B*2, } \\
\hline B39 & 0.065 & 0.039 & $6 \cdot 7$ & $9.8 \times 10^{-3}$ \\
\hline
\end{tabular}

${ }^{*} n=158($ HLA); $n=117$ (C4).

DRw8 this finding is likely to be very significant. The Bf S allotype was present in $92 \%$ of the C4B 2 positive patients.

\section{HLA and complement haplotypes}

Selected haplotype frequencies and linkage disequilibria in the patients between the HLA loci, and between the HLA and complement loci are presented in Table 5. Established gametic associations in Caucasians, ${ }^{36}$ which are present in this population, are not included in the table.

HLA antigens B39 and DRw8 were in strong linkage disequilibrium $(\mathrm{HF}=0.068, \Delta \mathrm{r}=0.82)$, which compares with controls $(\mathrm{HF}=0.005$, $\Delta r=0 \cdot 37)$. Similarly, the linkage and haplotype frequency of the complement alleles $\mathrm{C}_{4} \mathrm{~A}^{*} 4$ and $\mathrm{C}^{4} \mathrm{~B}^{*} 2$ were much greater in the patients $(\mathrm{HF}=0.091, \Delta \mathrm{r}=0.92)$ than those found in the controls $(\mathrm{HF}=0.024, \Delta \mathrm{r}=0.62)$. The 'null' allele

Table 4 Distribution of DR5 and DRw8 phenotypes in pauci-JCA patients and controls

\begin{tabular}{|c|c|c|c|c|c|c|}
\hline \multirow[t]{2}{*}{$\begin{array}{l}\text { DR } \\
\text { phenotype }\end{array}$} & \multicolumn{2}{|c|}{$\begin{array}{l}\text { Patients } \\
(n=158)\end{array}$} & \multicolumn{2}{|c|}{$\begin{array}{l}\text { Controls } \\
(n=192)\end{array}$} & \multirow[t]{2}{*}{$\begin{array}{l}\text { Relative } \\
\text { risk }\end{array}$} & \multirow[t]{2}{*}{$\begin{array}{l}\text { Fisher's } \\
p\end{array}$} \\
\hline & No & $\%$ & No & $\%$ & & \\
\hline DR5, $0^{*}$ & 1 & 0.6 & 2 & $1 \cdot 0$ & $0 \cdot 6$ & NS \\
\hline DR5, $\mathrm{X}^{+}$ & 28 & $17 \cdot 7$ & 24 & $12 \cdot 5$ & 1.5 & NS \\
\hline DRw8, $0^{*}$ & 1 & 0.6 & 2 & 1.0 & 0.6 & NS \\
\hline DRw8, $X^{+}$ & 43 & $27 \cdot 2$ & 10 & $5 \cdot 2$ & $6 \cdot 8$ & $7 \cdot 1 \times 10^{-9}$ \\
\hline DR5, w8 & 18 & 11.4 & 1 & 0.5 & $24 \cdot 6$ & $3.9 \times 10^{-6}$ \\
\hline Total & 91 & $57 \cdot 6$ & 39 & $20 \cdot 3$ & $5 \cdot 3$ & $4.8 \times 10^{-12}$ \\
\hline
\end{tabular}

*No DR antigen detected. Homozygosity confirmed on genotyping.

${ }^{+} \mathrm{DR}$ antigen other than DR5 or DRw8. 
Table 6 Selected HLA antigen frequencies $(\%)$ in pauci-JCA patients in relation to sex and age of onset

\begin{tabular}{|c|c|c|c|c|c|c|c|c|}
\hline \multirow[t]{3}{*}{$H L A$} & \multicolumn{6}{|c|}{ Age of onset (years) } & \multirow{2}{*}{\multicolumn{2}{|c|}{$1-9$}} \\
\hline & \multicolumn{3}{|l|}{$1-5$} & \multicolumn{2}{|l|}{$6-9$} & \multirow[b]{2}{*}{$\begin{array}{l}\text { Sub } \\
\text { total } \\
(n=21)\end{array}$} & & \\
\hline & $\begin{array}{l}\sigma \\
(n=28)\end{array}$ & $\begin{array}{l}\stackrel{+}{+} \\
(n=109)\end{array}$ & $\begin{array}{l}\text { Sub } \\
\text { total } \\
(n=1.37)\end{array}$ & $\begin{array}{l}\sigma \\
(n=8)\end{array}$ & $\begin{array}{l}q \\
(n=1.3)\end{array}$ & & $\begin{array}{l}\sigma \\
(n=36)\end{array}$ & $\begin{array}{l}q \\
(n=122)\end{array}$ \\
\hline A2 & 93 & 76 & 79 & 75 & 85 & 81 & 89 & 77 \\
\hline $\mathrm{B} 27$ & 7 & 8 & 8 & 12 & 23 & 19 & 8 & 10 \\
\hline Bw62 & 32 & 10 & 15 & 37 & 0 & 14 & 33 & $y$ \\
\hline DR4 & 11 & 5 & 7 & 25 & 23 & 24 & 14 & 7 \\
\hline DR5 & 26 & 29 & 28 & 37 & 38 & 38 & 28 & 30 \\
\hline DRw8 & 30 & 41 & 39 & 25 & 38 & 33 & 31 & 40 \\
\hline
\end{tabular}

${ }^{*}$ Values compared $p=8.5 \times 10^{4}$.

Values compared $\mathrm{p}=2.4 \times 10^{2}$

C4B*QO showed a weak linkage with DRw6 $\left(\Delta=0.031, \quad \chi^{2}=4 \cdot 4, \quad p<0 \cdot 04\right)$. There were also linkage disequilibria shown between the alleles $\mathrm{C}_{4} \mathrm{~B}^{*} 2$, and possibly $\mathrm{C}_{4} \mathrm{~A}^{*} 4$, and each of the HLA antigens B39 and DRw8. In families of DRw8, C4B 2 positive patients, which are currently being typed to ascertain haplotypes, the DRw8, C4B*2 alleles cosegregated in six, possibly all seven of the probands investigated so far. These observations suggested the presence in these pauci-JCA patients of the haplotype HLA-DRw8, C4B*2, HLA-B39, and the results of a calculation for three point linkage disequilibrium between these alleles supported this conclusion (Table 5).

Demonstrable linkage disequilibria involving the complement $\mathrm{Bf}$ locus were confined to weak positive associations between $\mathrm{Bf}^{*} \mathrm{~S}$ and DR5 $(\Delta=0.054$, $\left.\chi^{2}=4 \cdot 4, p<0 \cdot 04\right)$ and $\mathrm{Bf}^{*} \mathrm{~F}$ and DRw6 $(\Delta=0.043$, $\left.\chi^{2}=5 \cdot 4, p<0 \cdot 03\right)$, with a strong negative association of $\mathrm{Bf}^{*} \mathrm{~F}$ and DR5 $\left(\Delta=-0 \cdot 074, \chi^{2}=18 \cdot 2, \mathrm{p}=1 \cdot 4 \times 10^{-6}\right)$.

The antigen DR5 associated with pauci-JCA failed to show any haplotypic or phenotypic associations with alleles of loci other than the Bf locus.

The frequent antigen HLA-A2 did not show the normal Caucasoid linkages with HLA-B44, Bw60, Bw62, ${ }^{36}$ nor with any other alleles (Table 5). To try to explain the prevalence of this antigen, possible associations with the DR5 and DRw8 phenotypes were sought. The frequency of A2 was similar in DR5 $(84 \%)$ and DRw8 $(73 \%)$ positive patients and showed no difference between those carrying DR5 and/or DRw8 (77\%) and those negative for both antigens $(78 \%)$. Similar analysis of patients compared with controls confirmed a higher frequency of A2 in patients irrespective of the presence or absence of the DR5 or DRw8 phenotypes.

Table 7 Selected HLA antigen frequencies (\%) in pauci-JCA patients in relation to: antinuclear antibody (ANA); chronic iridocyclitis (CIR); and disease course: persistent pauciarticular; extended to five to nine joints; and extended to greater than nine joints

\begin{tabular}{|c|c|c|c|c|c|c|c|c|c|}
\hline \multirow[t]{2}{*}{$H L A$} & \multicolumn{2}{|l|}{$A N A$} & \multirow[b]{2}{*}{$p$} & \multicolumn{3}{|l|}{$C I R$} & \multicolumn{3}{|l|}{ Course } \\
\hline & $\begin{array}{l}+ \\
(n=110)\end{array}$ & $\begin{array}{l}- \\
(n=48)\end{array}$ & & $\begin{array}{l}+ \\
(n=84)\end{array}$ & $\begin{array}{l}- \\
(n=74)\end{array}$ & $p$ & $\begin{array}{l}\text { Pauci } \\
(n=4 I)\end{array}$ & $\begin{array}{l}5-9 \\
(n=47)\end{array}$ & $\begin{array}{l}>9 \\
(n=70)\end{array}$ \\
\hline A2 & 84 & 67 & $<0 \cdot(02$ & 84 & 72 & $<0.05$ & 83 & 83 & 73 \\
\hline B44 & 29 & 37 & NS & 24 & 40 & $<0 \cdot 03$ & 24 & 39 & 30 \\
\hline Bw62 & 15 & 12 & NS & 20 & 8 & $<0 \cdot(03$ & $22^{*}$ & 19 & $7^{*}$ \\
\hline DR2 & 18 & 31 & NS & 23 & 22 & NS & 20 & 21 & 24 \\
\hline DR4 & 6 & 17 & $<0.05$ & 8 & 11 & NS & 5 & 6 & 14 \\
\hline DR5 & 35 & 19 & $<0 \cdot 04$ & 28 & 32 & NS & 32 & 35 & 26 \\
\hline DR7 & 6 & 15 & NS & 9 & 8 & NS & 2 & 8 & 13 \\
\hline DRw8 & 43 & 31 & NS & 37 & 42 & NS & 44 & 38 & 37 \\
\hline
\end{tabular}

Values compared $\mathrm{p}<0 \cdot 03$.

All other comparisons between disease course subgroups were not significant at the $5 \%$ probability level. 
Table 8 Linkage disequilibria $(\Delta)$ between $H L A-D R w 8, C 4 A^{*} 4$, and $C 4 B^{*} 2$ in pauci-JCA patients classified by ANA status and by disease course

\begin{tabular}{|c|c|c|c|c|c|c|}
\hline \multirow{3}{*}{$\begin{array}{l}\text { Patient } \\
\text { subgroup }\end{array}$} & \multicolumn{6}{|c|}{ Haplotype } \\
\hline & \multicolumn{3}{|c|}{$D R w 8, C 4 A^{*} 4$} & \multicolumn{3}{|c|}{$D R w 8, C 4 B^{*} 2$} \\
\hline & $\Delta$ & $x^{2}$ & Fisher's $p$ & $\Delta$ & $x^{2}$ & Fisher's $p$ \\
\hline ANA negative $(n=30)$ & 0.009 & $0 \cdot 0$ & NS & $0 \cdot 036$ & $1 \cdot 0$ & NS \\
\hline ANA positive $(n=86)$ & 0.026 & $2 \cdot 5$ & NS & $0 \cdot 061$ & $8 \cdot 5$ & $2 \cdot 0 \times 10^{-3}$ \\
\hline Persistent paucis $(n=27)$ & -0.012 & $0 \cdot 0$ & NS & 0.054 & 0.9 & NS \\
\hline Extended $<9$ joints $(n=31)$ & $-0 \cdot 012$ & $0 \cdot 0$ & NS & 0.007 & $0 \cdot 0$ & NS \\
\hline Extended $>9$ joints $(n=58)$ & 0.049 & $7 \cdot 0$ & $7.9 \times 10^{-3}$ & 0.077 & $11 \cdot 0$ & $9.0 \times 10^{-4}$ \\
\hline
\end{tabular}

DISTRIBUTION OF GENETIC MARKERS IN CLINICAL SUBGROUPS

The pauci-JCA population was classified by disease features and the HLA and complement distribution compared.

\section{Sex, age of onset}

Selected HLA antigen frequencies in patients in relation to sex, early age of onset of disease (1-5 years), and later onset (6-9 years) are given in Table 6 .

The normal level of DR4 in the later onset subgroup contrasted with a significantly reduced frequency in early onset. The antigen Bw62 was significantly more common in boys when compared with both controls and with girls in either onset group.

\section{Antinuclear antibody, chronic iridocyclitis}

Of the 84 patients with CIR, $66(79 \%)$ also carried ANA; of the 74 cases without CIR, 44 (59\%) were ANA positive $(\mathrm{p}<0 \cdot 008)$.

As shown in Table 7 the DR5 frequency in the ANA positive group was increased compared with that of controls but approached normal frequency in the absence of ANA $(p<0.04)$. DRw8 levels were maintained above normal in both subgroups, though were higher in the presence of ANA. Both DR2 and DR4 correlated negatively with ANA, being less frequent in the ANA positive group relative to both normal values and the ANA negative cases (DR2: $\mathrm{p}<0.06$, DR4: $\mathrm{p}<0 \cdot 05$ ). Additionally, HLA-A2 was more prevalent in patients with ANA than in those without $(\mathrm{p}<0 \cdot 02)$.

The CIR analysis showed a different pattern of association (Table 7). There were no demonstrable DR differences, but the incidence of B44 was reduced in the presence of CIR, and above normal frequency in its absence $(p<0 \cdot 03)$, whereas Bw62 presented a reciprocal pattern $(\mathrm{p}<0 \cdot 03)$. HLA-A2 showed an enhanced association with the presence of CIR $(\mathrm{p}<0 \cdot 05)$.

Further partitioning of these data (not shown here) confirmed a correlation of both DR5 and CIR with ANA positivity, and an exceptionally strong association of HLA-A2 with the presence together of ANA and CIR (frequency $=88 \%, p<0.01$ ). Complement allotype distribution did not deviate significantly between any of the subgroups compared.

Of the $18 \mathrm{DR} 5$, w8 heterozygotes, 16 were positive for ANA $(\mathrm{RR}=3.9, \mathrm{p}<0.05)$, and 69 ANA positive patients $(63 \%)$ carried DR5 or DRw8, or both $(\mathrm{p}<0.04)$.

The DRw8, C4B 2 phenotype occurred more often in the group with ANA (22\%) than in those without ANA $(13 \%)(p=N S)$. Haplotype analysis showed linkage disequilibrium between these two alleles in the ANA positive patients, not evident in the absence of ANA (Table 8), and which was greater than that found in the total study group $(\Delta \mathrm{r}=4.6 v 4.0)$.

\section{Disease course}

Patients were divided between those following a persistent pauciarticular course for at least five years, those extending to five to nine joints involved, and those extending to more than nine joints.

Individual complement and $\overline{\mathrm{HL}} \overline{\mathrm{A}}$ antigen frequencies did not differ significantly between these subgroups, other than that of Bw62 which was increased in patients with persistent pauci-JCA and in those with five to nine joints involved (Table 7).

The DRw8, C4B*2 alleles were found in linkage disequilibrium in the severely extended group but not in those patients more mildly affected (Table 8). This haplotypic association was substantially stronger than that of the total study group $(\Delta r=$ $5.4 \vee 4.0)$.

\section{INHERITANCE OF SUSCEPTIBILITY}

Fig. 1 depicts estimates of relative risks of the disease for the DR5 and DRw8 phenotypes, calculated against the absence of DR5 and DRw8 in 
patients and controls. ${ }^{37}$ Also indicated are $95 \%$ confidence limits of risks following usual statistical practice. Significant heterogeneity for the risks was shown $\left(\chi^{2}=14.0, p<0.008\right)$ due primarily to the very high risk for DR5, w8 heterozygotes $(R R=41 \cdot 1$, $\left.\mathrm{p}=1.3 \times 10^{-8}\right)$, and to a much lesser extent for DRw8, $X$ heterozygotes $\left(R R=9.8, p=1 \cdot 4 \times 10^{-11}\right)$.

The Hardy-Weinberg fit for the DR5 and DRw8 phenotypes is presented in Table 9. Gene frequencies were estimated by the gene counting method of maximum likelihood. There was a lack of HardyWeinberg equilibrium in this disease population, with a significant excess of DR5, w8 heterozygotes present and a deficit of the corresponding homozygotes. The observed number of DRw8, X heterozygotes was as expected from the increased incidence of DRw8 in these patients. Similarly, the DRw6 positive phenotypes did not differ from expected numbers.

These are findings inconsistent with the hypothesis of a recessive mode of inheritance of susceptibility to pauci-JCA and point to an additive, 'overdominance' effect of DR5, w8 heterozygotes.

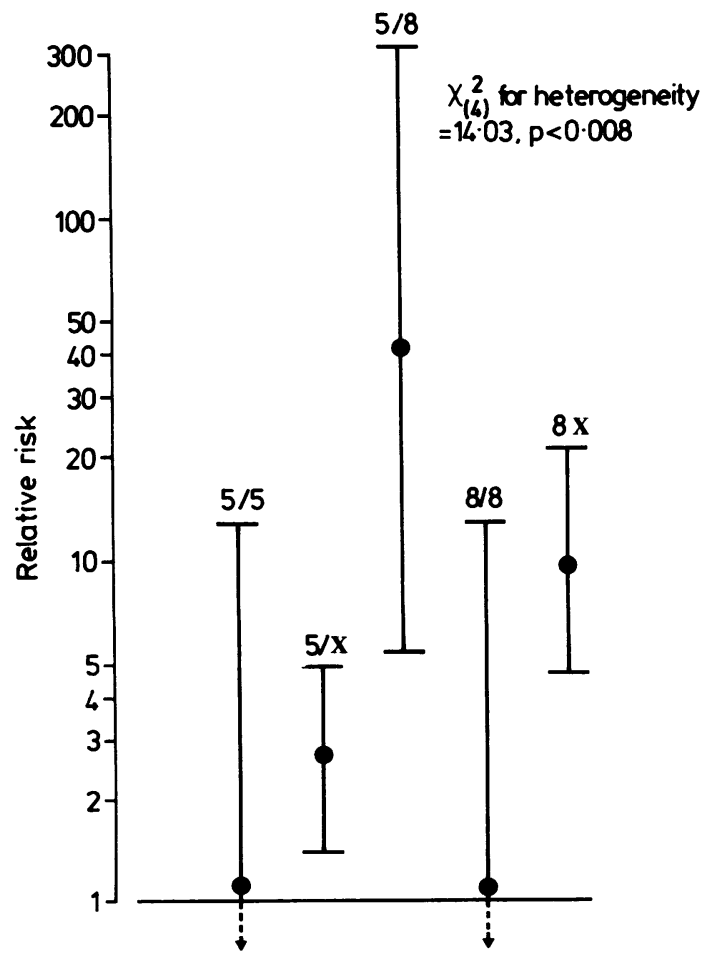

Fig. 1 Relative risk of pauci-JCA for DR5 and DRw8 phenotypes. Relative risks are calculated against the non-DR5, -DRw8 group. Bars indicate $95 \%$ confidence intervals of relative risks.
Table 9 Deviation from Hardy-Weinberg equilibrium in pauci-JCA patients

\begin{tabular}{lccc}
\hline $\begin{array}{l}\text { DR } \\
\text { phenotype }\end{array}$ & Number & & \multicolumn{1}{l}{$\chi^{2}$} \\
\cline { 2 - 3 } & Observed & Expected & \\
\hline 5,5 & 1 & $3 \cdot 65$ & $1 \cdot 92$ \\
5, X & 28 & $31 \cdot 14$ & $0 \cdot 32$ \\
w8, w8 & 1 & $6 \cdot 28$ & $4 \cdot 44$ \\
w8, X & 43 & $40 \cdot 87$ & $0 \cdot 11$ \\
5, w8 & 18 & $9 \cdot 57$ & $7 \cdot 43$ \\
X, X & 67 & $66 \cdot 49$ & $0 \cdot 00$ \\
& & & \\
Total & 158 & $158 \cdot 00$ & $\chi_{(3)}^{2}=14 \cdot 22$ \\
& & & $\mathrm{p}<0.003$ \\
\hline
\end{tabular}

\section{Discussion}

GENETIC ASSOCIATIONS IN EARLY ONSET PA U C I - J C A

The significantly increased incidence of the C4B 2 variant and C4A 4, B 2 phenotype in this study is the first reported association of this disease with complement allotypes. Increases of C4B 2 were found in other pauci-JCA populations but were not significant. ${ }^{19} 24$ Disease associations with C4B 2 have also been reported in Alzheimer's disease and multiple sclerosis. ${ }^{38}{ }^{39}$ Other recorded $\mathrm{C} 4$ associations are with the 'null' alleles $\mathrm{C} 4 \mathrm{~A}^{*} \mathrm{QO}$ and $\mathrm{C}^{4} \mathrm{~B}^{*} \mathrm{QO}$ in several autoimmune disorders. ${ }^{41}$ Apart from a weak linkage of $C 4 B^{*} \mathrm{QO}$ and DRw6, there was no evidence here of involvement of the 'null' alleles. This was not surprising in view of the normal or raised serum complement levels found in JCA. ${ }^{41}$

We have shown novel observations of disease associations with phenotypic combinations of HLAB39, -DRw8, C4A 4, C4B 2, and of linkage disequilibria between these alleles, with increased haplotype frequencies. Increased frequencies in patients with early onset JCA were reported of the common, DR5 associated haplotype C4A*3, C4B*1, $\mathrm{Bf}^{*} \mathrm{~S},{ }^{19}{ }^{23}$ the uncommon haplotype $\mathrm{C} 4 \mathrm{~A}^{*} 3, \mathrm{C} \mathrm{B}^{*} 2$, $\mathrm{Bf}^{*} \mathrm{~S}$, and in late onset B27 associated cases of the $\mathrm{C}_{4} \mathrm{~A}^{*} 4, \mathrm{C} 4 \mathrm{~B}^{*} 2, \mathrm{Bf}^{*} \mathrm{~S}$ haplotype. ${ }^{23}$ In the present study $C 4 A^{*} 3, C 4 B^{*} 1$ phenotype and haplotype frequencies were less than in controls. The nonavailability for this study of a control population both HLA and complement typed precluded direct comparisons with the HLA/complement results in the patients. The normally low incidence of DRw8, however, requires a comparatively large control population to evaluate any but strong linkages with this allele. In normal Caucasians included in the 9th Workshop $^{36}$ DRw8, C4B*2 were not found in linkage disequilibrium and had a relative delta value of $\Delta r=0.08$ and haplotype frequency $\mathrm{HF}=0.004$ compared with $\Delta r=0 \cdot 40, \mathrm{HF}=0.090$ in our pauciJCA patients. Thus the occurrence of a haplotypic 
association between DRw8 and C4B*2, which is supported by preliminary family data, is likely to be unique to these patients. The striking relationship of the B39, DRw8 alleles we report may reflect a functionally significant HLA-DQ $\alpha$ chain variation. as has been suggested for the B15, DR4 associated effect in type 1 diabetics. ${ }^{42}$ These results require verification in further family studies but, taken with the phenotype data, they imply an increased frequency in this pauci-JCA population of a supratype. and possibly an extended haplotype comprising DRw8, Bf*S, C4A*4, C4B*2, B39.

The multiple associations with HLA antigens confirm and extend earlier reports. ${ }^{3-20}$ The increase of A2 was unrelated to increases in other antigens, in agreement with reported family data. ${ }^{19}$ Associations with DR5 and DRw8, both singly and in combination, were confirmed, with $58 \%$ of patients possessing either or both antigens. The presence of DRw8 confers an almost 13-fold risk of the disease, which, together with the substantial EF $(\delta)$ value, signify linkage of this allele to a disease susceptibility gene. In contrast with earlier findings ${ }^{4} 619$ the DR5 increase was less marked, possibly reflecting racial differences between studies. Reports of a significant increase in DRw6 incidence ${ }^{12} 1315$ were not substantiated. The lack of a decrease in this antigen to compensate for increases in other alleles, however, may itself be significant. Recently defined serological subtypes of DR5 (DRw11, DRw12) and DRw6 (DRw13, DRw14) ${ }^{43}$ may show a stronger association with pauci-JCA. We confirm significant negative correlations with DR4, DR7, and DRw53. The DR4 decrease might be a compensatory one, but the paucity of DR7 positive cases indicates linkage of this allele to a disease resistance gene.

The linkage disequilibrium between the DRw8, $\mathrm{C}^{\mathrm{B}} \mathrm{B}^{*} 2$ alleles found in the total patient group resided primarily and more strongly in the ANA positive subgroup and in those who had extended to over nine joints involved. Confirmation of this finding would indicate that the DRw8, C4B*2 haplotype predisposes to more severe disease. A correlation between ANA seropositivity and DR5 was confirmed ${ }^{4}{ }^{20}$ but that reported between ANA and DRw8 $8^{15}{ }^{1720}$ was not evident; the presence of both antigens, however, carried a fourfold increased risk amongst patients of having circulating ANA. Contrary to the results of previous studies, ${ }^{4}{ }^{12}$ the CIR positive group was not associated with any DR antigens, but showed an increase of Bw62 and decrease of B44. The antigen HLA-A2 associated preferentially with CIR, confirming an earlier report, ${ }^{19}$ and also with ANA, with a high incidence $(88 \%)$ seen in the presence of both disease features, possibly implicating this antigen in disease pathogenesis. Classification by sex and age of onset provided no indication of disease heterogeneity other than an increase of Bw62 in males, and an absence in later onset cases of the abnormally low DR4 frequency shown in the total patient group. The DR4 observation supports an earlier finding, ${ }^{20}$ but reports of a lack of association in later onset males with HLA-A2, DR5, and DRw $8^{9}{ }^{19}$ are not substantiated.

A consistent feature of all subgroups of patients divided by disease parameters was the pattern of strong association with the HLA antigens A2, DRw8, and DR7, implying the sharing of a similar background of genetic susceptibility. It may be concluded that the clinical variations encountered are manifestations of the one disease as classified by mode of onset.

IN HERITANCE OF SUSCEPTIBILITY TO

EARLY ONSET PAUCI-JCA

The lack of fit to Hardy-Weinberg expectations we report for DR5, DRw8 phenotypes is incompatible with a recessive mode of inheritance of susceptibility. A similar view was expressed in the 9th Workshop pauci-JCA report, though some of the data differed from those of the present study. ${ }^{19}$ This discrepancy between studies could be attributed to racial or clinical heterogeneity, or the features we describe may be characteristic of the disease in British patients. Investigations of double case, sib pair families have shown significantly increased haplotype sharing in pauci-JCA but no consensus about the mode of inheritance of susceptibility. ${ }^{19} 2122$

This study has shown an excess in both the frequency of and risk for DR5, w8 heterozygotes over those for both of the homozygotes. The standard deviations of risks tend to be large, but these observations together are evidence to discount dominant, recessive, and intermediate models of inheritance and introduce the concept in pauci-JCA of at least two different DR linked susceptibility alleles or genes, possibly acting through separate pathogenetic pathways. The affected sib pair data, showing that both haplotypes contribute to susceptibility in most cases, support this hypothesis. ${ }^{19} 2122$ Moreover, the possible greater risk for the DR5, w8 heterozygote than for the sum of the other heterozygotes, DR5, X and DRw8, X, may indicate that the effect of the DR linked genes is more than just additive. Such a mechanism, involving the DR related HLA-DQ locus, might be the generation of hybrid antigens in particular heterozygotes by gene trans-complementation, ${ }^{44}$ which may be implicated in enhanced susceptibility to certain other diseases. ${ }^{42} 4546$ 
Further 'disease' genes in linkage with A2, DR7, and possibly DR4 and DRw6, may contribute to the final susceptibility status of the individual. Also, since the genetic associations and the penetrance of the disease gene(s) are incomplete there are likely to be additional factors predisposing to pauci-JCA.

POSSIBLE MECHANISMS OF SUSCEPTIBILITY TO EARLY ONSET PA U CI-J CA

It is clear from the accumulation of HLA data ${ }^{3-22}$ and the reported abnormalities in the immune system, ${ }^{41}$ that there is a strong immunogenetic component of susceptibility to pauci-JCA. Possible mechanisms of susceptibility underlying the associations with three classes of major histocompatibility complex (MHC) gene products observed in this study can be considered.

The singular association, particularly of ANA, CIR positive cases, with the class I antigen HLA-A2 is intriguing. MHC class I molecules function as recognition elements, and possibly receptors, in the host response to a variety of foreign exogenous antigens, ${ }^{47}$ and these mechanisms may underly the known association of certain diseases with these products. ${ }^{48}$ Polymorphism within the serologically defined $\mathrm{A} 2$ antigen has been recognised, ${ }^{49}$ and at least four distinct subtypes which are functionally important have been detected. ${ }^{50} 51$ The implication in susceptibility to pauci-JCA of an interaction between an HLA-A2 molecule and a foreign agent, such as a pathogen, becomes an attractive notion.

Strong associations found with the class II antigens DRw8 and DR7, apparent in all clinical subgroups, indicate linkage to major immuneresponse (Ir) or immune suppression (Is) genes, or both, controlling disease susceptibility and resistance respectively. The DR5 association was weaker and correlated with ANA seropositivity. This DR5 expression in pauci-JCA, and in other autoimmune related diseases, ${ }^{52-55}$ may reflect a generalised difference in the immune response to autoantigen effected by a DR linked, non-antigen specific Ir/Is determinant, as proposed for the DR3 associated group of autoimmune related disorders. ${ }^{45} 56$ Further Ir/Is determinants weakly linked to DR2 and DR4 may be present, having a protective role against autoantigen. ${ }^{57}$

Implication of complement in the pathogenesis of this disease is evidenced by its reported activation, particularly via the classical pathway, and possible formation of immune complexes. ${ }^{41}$ The contribution of complement system components and MHC encoded gene products in immune defence is known, ${ }^{58} 59$ and their direct involvement in certain DR associated diseases is assumed. ${ }^{(6)}$ The concept has been discussed of clusters of linked MHC genes with inter-related functions, where selective interactions favour closer linkage disequilibrium. ${ }^{57} 61$ Our findings give rise to the speculation that susceptibility to early onset pauciJCA may be mediated through the interaction of a DRw8 related Ir gene and linked complement $\mathrm{C}_{4} \mathrm{~B}^{*} 2$ gene, leading to a defective immune response to unknown antigen(s).

Finally, evidence from this study suggests a role for the HLA-DQ locus in determining susceptibility to pauci-JCA. DNA analysis is revealing substantial genetic variation in the HLA-D region, particularly in the DQ $\alpha$ chain, ${ }^{62}$ which is likely to play an important functional part in resistance to disease, such as through immune response differences. ${ }^{42}$ The reported DNA level polymorphism is correlated with HLA-DR and -DQ types, but in addition, some variation within DR types, such as DR5, has been detected..$^{63}$ There may be a closer relation between early onset pauciarticular JCA and a DNA defined subtype of DR5 or a putative variant of DRw8, or both, than that shown by serology.

The authors wish to thank the many HLA centres who generously donated typing sera, in particular, Dr Ben Bradley, UKTS, Bristol for the bulk of the ABC typing panel, and Drs Ieke Schreuder and $\bar{O}$ Jon van Rood, University Hospital, Leiden for a nucleus of excellent DR antisera. We are indebted to Dr Julia Bodmer, Imperial Cancer Research Fund Laboratories, London for making available HLA control data. The constructive advice given by $\operatorname{Dr} O$ Stella Knight during the preparation of this manuscript is gratefully acknowledged.

\section{References}

1 Ansell B M. Chronic arthritis in childhood. Ann Rheum Dis 1978; 37: $107-20$.

2 Bywaters E G L. Juvenile chronic arthritis. In: Ziff M. Velo G, Gorini S, eds. Rheumatoid arthritis. New York: Raven, 1982: O 179-90. (Ziff M. Velo G, Gorini S, eds. Advances in inflammation research; vol, 3).

3 Stastny P. Fink C W. Different HLA-D associations in adult and juvenile rheumatoid arthritis. J Clin Invest 1979; 63: $\frac{D}{2}$ 124-30.

4 Glass D, Litvin D, Wallace K, et al. Early-onset pauciarticular N juvenile rheumatoid arthritis associated with human leucocyte antigen-DRw5, iritis, and antinuclear antibody. J Clin Invest $N$ 1980; 66: 426-9.

5 Stastny P. Joint report: rheumatoid arthritis. In: Terasaki P, ed. $\omega$ Histocompatibility testing 1980. Los Angeles: UCLA Tissuc Typing Lab, 1980: 681-6.

6 Suciu-Foca N, Jacobs J, Godfrey $M$, et al. HLA-DR5 in $\frac{C}{(\Phi)}$ juvenile rheumatoid arthritis confined to few joints. Lancet $\mathscr{D}$ 1980; ii: 40 .

7 Steiger U, Barbanti M, Garotta G, et al. Association of HLA- T Bw39 and DRw8 with a variant of juvenile chronic polyarthritis. In: Terasaki P, ed. Histocompatibility testing 1980. Los Angeles: UCLA Tissue Typing Lab, 1980: 954.

8 Morling N, Hellesen C, Jakobsen B K, et al. HLA-A, B, C, D, 릉 DR antigens and primed lymphocyte typing (PLT) defined DPantigens in juvenile chronic arthritis. Tissue Antigens 1981; 17: 433-41. 
9 Oen K, Petty R E, Schroeder M-L. An association between HLA-A2 and juvenile rheumatoid arthritis in girls. $J$ Rheumatol 1982; 9: 916-20.

10 Balogh Z, Gyodi E, Petranyi G, Meretey K, Bozsoky S. HLADR antigens in juvenile chronic arthritis. J Rheumatol 1982; 9: 448-50.

11 Fink C W, Stastny P. HLA-DR typing in juvenile arthritis. In: Ziff M, Velo G, Gorini S, eds. Rheumatoid arthritis. New York: Raven, 1982: 191-4. (Ziff M, Velo G, Gorini S, eds. Advances in inflammation research; vol 3 ).

12 Schaller J G, Hansen J. Early childhood pauciarticular juvenile rheumatoid arthritis: clinical and immunogenetic studies [Abstract]. Arthritis Rheum 1982; 24: S63.

13 Reekers P. Schretlen E D A M, van de Putte L B A. Increase of HLA- 'DRw6' in patients with juvenile chronic arthritis. Tissue Antigens 1983; 22: 283-8.

14 Førre $\emptyset$, Dobloug J H, Høyeraal H M, Thorsby E. HLA antigens in juvenile arthritis. Arthritis Rheum 1983; 26: 35-8

15 Sher M R, Schultz J S, Ragsdale C G, Kapur J J, Sullivan D B, Cassidy J T. HLA-DR/MT typing identifying possible immunogenetic mechanisms for juvenile rheumatoid arthritis [Abstract]. Arthritis Rheum 1983; 26: S58.

16 Miller M, Fraser P, Petersen P, Chylack L. Glass D. MB/MT gene frequencies in pauciarticular juvenile arthritis with iridocyclitis [Abstract]. Pediatr Res 1983; 17: 419.

17 Moore T L, Oldfather J W, Osborn T G, et al. HLA antigens in black and white patients with juvenile arthritis: associations with rheumatoid factor, hidden rheumatoid factor, antinuclea antibodies, and immune complex levels. $J$ Rheumatol 1984; 11 : 188-96.

18 Miller M L. Fraser P A. Jackson J M. et al. Inherited predisposition to iridocyclitis with juvenile rheumatoid arthritis: selectivity among HLA-DR5 haplotypes. Proc Natl Acad Sci USA 1984; 81: 3539-42.

19 Ansell B M. Albert E. Joint report: juvenile chronic arthritis. pauciarticular type. In: Albert E D. Baur M P. Mayr W R, eds. Histocompatibility testing 1984. Berlin: Springer 1985: 368-74.

20 Sher M R. Schultz J S. Ragsdale C G, Kapur J J, Sullivan D B, Cassidy J T. HLA-DR and MT associations with the clinical and serologic manifestations of pauciarticular onset juvenile rheumatoid arthritis. $J$ Rheumatol 1985: 12: 114-8.

21 Suciu-Foca N, Godfrey M. Jacobs J, et al. Increased frequency of DRw5 in pauciarticular JRA. In: Terasaki P. ed. Histocompatibility testing 1980. Los Angeles: UCLA Tissue Typing Lab. 1980; 953

22 Clemens L E. Albert E, Ansell B M. Sibling pairs affected by chronic arthritis of childhood: evidence for a genetic predisposition. J Rheumatol 1985: 12: 108-13.

23 Raum D. Awdeh Z, Glass D. Alper C A. MHC-linked complement haplotypes (complotypes) in juvenile rheumatoid arthritis (JRA) [Abstract]. Clin Res 1981: 29: 559A.

24 Arnaiz-Villena A. Gomez-Reino J J. Gamir M L. et al. DR. C4. and $\mathrm{Bf}$ allotypes in juvenile rheumatoid arthritis. Arthritis Rheum 1984: 27: 1281-5.

25 Bodmer W F, Bodmer J G. Cytofluorochromasia for HLA-A, -B, -C and DR typing. In: Ray J G Jr, Hare D B, Pedersen P D, Mullally D I, eds. N.I.A.D. manual of tissue typing techniques 1979-80. Bethesda: US Department of Health. Education, and Welfare, National Institutes of Health, 1980: 46-54.

26 van Rood J J. van Leeuwen A, Ploem J S. Simultancous detection of two cell populations by two-colour fluorescence and application to the recognition of B-cell determinants. Nature 1976; 262: 795-7.

27 Awdeh Z L, Alper C A. Inherited structural polymorphism of the fourth component of human complement (C4). Proc Natl Acad Sci USA 1980; 77: 3576-80.

28 Mauff G. Bender K, Giles C M, Goldman S Opferkuch W, Wachauf $\mathrm{B}$. Human $\mathrm{C} 4$ polymorphism: pedigree analysis of qualitative, quantitative, and functional parameters as a basis for phenotype interpretations. Hum Genet 1984; 65: 362-72.

29 Armitage P. Statistical methods in medical research. Oxford: Blackwell Scientific, 1971.

30 Svejgaard A, Jersild C, Staub-Nielsen L, Bodmer W F. HL-A antigens and disease, statistical and genetical considerations. Tissue Antigens 1974; 4: 95-105.

31 Bengtsson $\mathrm{B} O$, Thomson $\mathrm{G}$. Measuring the strength of associations between HLA antigens and diseases. Tissue Antigens 1981; 18: 356-63.

32 Green A. The epidemiologic approach to studies of association between HLA and disease. Tissue Antigens 1982; 19: 259-68.

33 Mattiuz P L, Ihde D, Piazza A, Ceppellini R, Bodmer W F. New approaches to the population genetic and segregation analysis of the HL-A system. In: Terasaki P I, ed. Histocompatibility testing 1970. Copenhagen: Munksgaard, 1970: 193-205.

34 Baur M P, Danilovs J A. Joint report: population analysis of HLA-A, B, C, DR, and other genetic markers. In: Terasaki P I, ed. Histocompatibility testing 1980. Los Angeles: UCLA Tissue Typing Lab, 1980: 955-93.

35 Piazza A. Haplotypes and linkage disequilibria from the threelocus phenotypes. In: Kissmeyer-Nielsen F, ed. Histocompatibility testing 1975. Copenhagen: Munksgaard, 1975 923-7.

36 Baur M P, Neugebauer M, Albert E D. Reference tables of two-locus haplotype frequencies for all MHC marker loci. In: Albert E D, Baur M P. Mayr W R, eds. Histocompatibility testing 1984. Berlin: Springer, 1985: 677-755.

37 Svejgaard A, Ryder L P. HLA genotype distribution and genetic models of insulin-dependent diabetes mellitus. Ann Hum Genet 1981; 45: 293-8.

38 Nerl C W, Mayeux R, O'Neill G J. Complement C4 allotypes in Alzheimer's disease. Lancet 1982; ii: 1343.

39 Schroder R, Zander H, Andreas A, Mauff G. Multiple sclerosis: immunogenetic analyses of sib-pair double case families. II. Studies on the association of multiple sclerosis with $\mathrm{C} 2, \mathrm{C} 4, \mathrm{Bf}, \mathrm{C} 3, \mathrm{C} 6$ and GLO polymorphisms. Immunobiology 1983; 164: 160-70.

40 Dawkins R L, Christiansen F T, Kay P H, et al. Disease associations with complotypes, supratypes and haplotypes. Immunol Rev 1983; 70: 5-22.

41 Moore $T$ L, Weiss $T$ D. Immunologic studies in juvenile arthritis. Bull Rheum Dis 1982: 32: 25-9.

42 Bodmer W, Bodmer J, Lee J, Spielman R, Travers P, Trowsdale J. Structure, evolution and polymorphism of the HLA-D region. In: Sasasuki T, Tada T, eds. Immunogenetics: its applications to clinical medicine. Orlando: Academic Press, 1984: 263-81.

43 Albert E D, Baur M P, Mayr W R, eds. Histocompatibility testing 1984. Berlin: Springer, 1985: 4-8.

44 Charron D J, Lotteau V, Turmel P. Hybrid HLA-DQ antigens: molecular expression. In: Albert E D, Baur M P, Mayr W R, eds. Histocompatibility testing 1984. Berlin: Springer, 1985: $539-43$.

45 Svejgaard A, Platz P, Ryder L P. HLA and disease 1982-a survey. Immunol Rev 1983; 70: 193-218.

46 Nepom B S, Nepom G T. Mickelson E, Schaller J G, Antonelli P, Hansen J A. Specific HLA-DR4-associated histocompatibility molecules characterize patients with seropositive juvenile rheumatoid arthritis. J Clin Invest 1984; 74: 287-91.

47 de Vries R R P, van Rood J J, eds. Immunobiology of HLA class-I and class-II molecules. Prog Allergy 1985; 36: 1-226.

48 Svejgaard A, Morling N, Platz P, Ryder L P, Thomsen M. HLA and disease. In: Fougereau M, Dausset J, eds. Immunology 80 , progress in immunology $I V$. New York: Academic Press, 1980: 530-40.

49 Biddison W E, Ward F F, Shearer G M, Shaw S. The self determinants recognised by human virus immune $T$ cells can be 
distinguished from the serologically defined HLA antigens. J Immunol 1980; 124: 548-52.

50 Van der Poel J J. Mölders H. Thompson A. Ploegh H L. Definition of four HLA A2 subtypes by CML typing and biochemical analysis. Immunogenetics 1983; 17: 609-21.

51 Gotch F M, Kelly C. Ellis S A, et al. Characterisation of the HLA-A2-2 subtype: T cell evidence for further heterogeneity. Immunogenetics 1985; 21: 11-23.

52 Farid N R. Sampson L. Moen H. Barnard J M. Goitrous autoimmune thyroiditis is associated with HLA-DR5. Tissue Antigens 1981; 17: 265-8.

53 Gladman D D. Keystone E C. Baron M. Lee D. Cane D. Mervart H. Increased frequency of HLA-DR5 in scleroderma. Arthritis Rheum 1981: 24: 850-3.

54 Thomsen M. Ryder L. P. Svejgaard A. Gimsing P. HLA and its associations with gastrointestinal diseases. In: Rotter $\mathrm{J}$ I, Samloff I M. Rimoin D L. eds. Genetics and heterogeneity of common gastrointestinal disorders. New York: Academic Press. 1980: $523-33$.

55 Mearin M L. Biemond I. Pena A S, et al. HLA-DR phenotypes in Spanish coeliac children: their contribution to the understanding of the genetics of the disease. Gut 1983: 24: 532-7.

56 Bodmer W F. The MHC and its role in the immune defence. In:
Fougereau M. Dausset J. eds. Immunology 80, progress in immunology IV. New York: Academic Press, 1980: 555-9.

57 Dausset J. Contu L. The MHC and immune response in man. In: Fougereau M. Dausset J. eds. Immunology 80. progress in immunology IV. New York: Academic Press. 1980: 513-29. 58 Hirsch R L. The complement system: its importance in the host response to viral infection. Microbiol Rev 1982; 46: 71-85.

59 Lachmann P J. Biology of the complement system: a summary. In: Yamamura Y. Tada T. eds. Progress in Immunology $V$. Tokvo: Academic Press. 1983: 445-52.

60) Rittner C. Bertrams J. On the significance of $\mathrm{C} 2, \mathrm{C} 4$ and factor B polymorphisms in disease. Hum Genet 1981; 56: 235-47.

61 Bodmer W F. Gene clusters and the HLA system. In: Human genetics: possibilities and realities. Oxford: Excerpta Medica, 1979: 205-23. (Ciba Foundation Symposium 66 New Series).

62 Trowsdale J. Lee J. Carey J. Grosveld F. Bodmer J. Bodmer W. Sequences related to HLA-DRe chain on human chromosome 6: restriction enzyme polymorphism detected with $D($ i 1 , chain probes. Proc Natl Acad Sci USA 1983: 80: 1972-6.

63 Spielman R S. Lee J. Bodmer W F. Bodmer J G. Trowsdale J Six HLA-D region a-chain genes on human chromosome 6 : polymorphisms and associations of DC $(\ell$-related sequences with DR types. Proc Natl Acad Sci USA 1984: 81: 3461-5. 